\title{
The Effect of Calcium Hydroxide on Fibroblast Cells Viability
}

\author{
Vincentia Adya Paramitta \\ Tetiana Haniastuti \\ Heni Susilowati \\ Department of Oral Biology, Faculty of Dentistry, \\ Universitas Gadjah Mada, Yogyakarta, Indonesia \\ E-mail:drgheni.susilowati@gmail.com \\ Received August 15, 2010; Accepted December 10, 2010
}

\begin{abstract}
Calcium hydroxide $\left[\mathrm{Ca}(\mathrm{OH})_{2}\right]$ is widely used as medicament in dental pulp and root canal therapy. Previous studies demonstrate the ability of calcium hydroxide to induce necrosis in dental pulp tissue. However, the mechanism of tissue destruction remains unknown. The aim of this study was to investigate fibroblast cell viability in response to calcium hydroxide exposure. In this study, Vero fibroblast cell line was treated with various concentrations of calcium hydroxide for 24 hours. Cell viability was measured by using MTT assay. Our results showed significant decrease in cell viability after exposed with calcium hydroxide at concentration 62.5 and $125 \mu \mathrm{g} / \mathrm{ml}$. The result indicated that calcium hydroxide induced cell death in Vero cell line in a dosedependent manner. This study suggests that fibroblast cell death may involved in the mechanism of pulp tissue necrosis caused by calcium hydroxide.
\end{abstract}

Keywords: Calcium hydroxide, cell viability.

\section{Introduction}

Dental pulp is a connective tissue that is uniquely situated within the rigid encasement of mineralizeddentin ${ }^{1}$. Fibroblast is the most distributed cell in the dental pulp tissue and widely distributed in cell-rich zone. Fibroblast main function is to synthesize colagen tipe I and III, which take part in tissue remodelling ${ }^{1,2}$.

Endodontic treatment is a procedure to maintain the health of the pulp and the periapical tissue ${ }^{3}$. Calcium hydroxide $\left[\mathrm{Ca}(\mathrm{OH})_{2}\right]$ has been widely used as medicament in endodontic treatment since Hermann used it for the first time in $1920^{4}$. This medicament is used in many dental treatments such as pulp capping, pulpotomy, apexification, rootperforation, andinternal or external root resorption ${ }^{5-11}$. Calcium hydroxide has antimicrobial effect ${ }^{5}$ that further more can give therapeutic effect and it has the ability to induce reparative dentin and dentinal bridge formation ${ }^{12}$. Previous in vivo study demonstrated the potencial of calcium hydroxide in inducing dental pulp tissue destructions ${ }^{13}$. However the underlying mechanism of tissue destruction is not well understood. As an initial step to clarify the molecular mechanism of $\mathrm{Ca}(\mathrm{OH})_{2}$-induced pulp tissue destruction, this study was subjected to investigate fibroblasts cell viability after $\mathrm{Ca}(\mathrm{OH})_{2}$ exposure in vitro. 


\section{Materials and Methods}

In this study, Vero fibroblast cells were cultured and maintained in M199 culture medium (Gibco, Paisley, UK) suplemented with $10 \%$ fetal bovine serum (Gibco), 2\% penicillin and streptomycin (Gibco), and $0.5 \%$ fungizone (Gibco). The confluent culture was harvested and plated into 96 wells plate for overnight incubation at $36^{\circ} \mathrm{C}$. The first group of cells $\left(2 \times 10^{4}\right.$ cells/well) was then treated with various concentrations of calcium hydroxide $(62.5 \mu \mathrm{g} /$ $\mathrm{ml}, 125 \mu \mathrm{g} / \mathrm{ml}$, and $250 \mu \mathrm{g} / \mathrm{ml}$ ), where as another one was left untreated as a negative control. Each concentration of calcium hydroxide was added to the cells and incubated for 72 hours in $5 \% \mathrm{CO}_{2}, 37^{\circ} \mathrm{C}$. All treatment was performed in 5 replications. Cell viability was then measured by using MTT assay. The following equation was used to find the percentage of Vero fibroblast cells viability ${ }^{13}$.

$$
\text { Viability }(\%)=\frac{\mathrm{OD} \text { in treated group }}{\mathrm{OD} \text { in negative control group }} \times 100 \%
$$

$O D=$ optical density

To determine whether the treatment of calcium hydroxide had significant effect on the cell viability, the data were analyzed by using one-way analysis of variance (ANOVA). The Post-Hoc least significant difference (LSD) test was done to determine the significance of difference among groups.

\section{Results and Discussion}

The result obtained in this study is presented in Figure 1 and Table 1 . The results of ANOVA demonstrated a significant decrease in cell viability after exposed with calcium hydroxide $(p<0.05)$, indicating that calcium hydroxide might have ability to induce cell death. In addition, Post-Hoc LSD test showed a significant difference $(p<0.05)$ between control group with all of the treated groups. The group treated with $62.5 \mu \mathrm{g} / \mathrm{ml}$ calcium hydroxide showed a significant difference with the groups treated with $125 \mu \mathrm{g} / \mathrm{ml}$ and $250 \mu \mathrm{g} / \mathrm{ml}$. No significant difference was found between the group treated with calcium hydroxide $125 \mu \mathrm{g} / \mathrm{ml}$ and $250 \mu \mathrm{g} / \mathrm{ml}$.

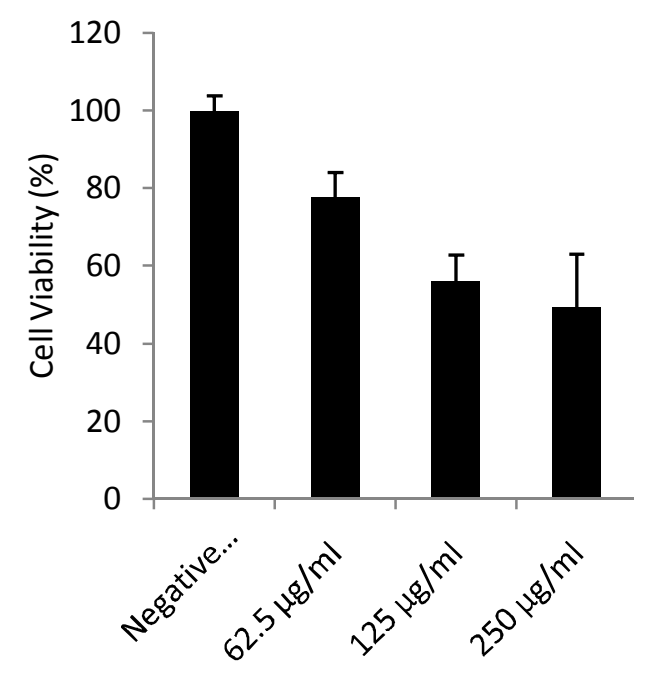

Figure 1. Calcium hydroxide induced cell death in Vero fibroblast cells. The untreated cells showed almost hundred percent living cells. The treatment of various concentrations of $\mathrm{Ca}(\mathrm{OH})_{2}$ caused cell death in dose-dependent manner $(p<0.05)$. The data were presented as means \pm SD of representative experiments.

Figure 1 and Table 1 demonstrate that the group treated with the largest concentration of calcium hydroxide $(250 \mu \mathrm{g} / \mathrm{ml})$ has the lowest percentage of viable cells. The increasing concentration of the calcium hydroxide added to the cells caused decrease in the percentage of viable Vero cells.

There are many types of preparation of calcium hydroxide used in dentistry. The types are available as points, setting, and non-setting ${ }^{14}$. Pure calcium hydroxide preparation was used in this study. The result of this study showed that $\mathrm{Ca}(\mathrm{OH})_{2}$ might have ability to induce fibroblast cell death. The result revealed that calcium hydroxide at concentration of $62.5 \mu \mathrm{g} / \mathrm{ml}$ or higher might cause cell death in Vero fibroblast cells. This phenomenon may have clinical implications as calcium hydroxide is widely used in dental treatments ${ }^{4}$. The reported clinical evidence provides factual information about the cytotoxic effect of this medicament ${ }^{13}$, but little is known about the underlying molecular mechanisms. 
Table 1. Means and standard deviations of the percentage of fibroblasts cell viability after calcium hydroxide treatment.

\begin{tabular}{cc}
\hline Groups & Cell Viability (\%) \pm SD \\
\hline Negative Control & $99.842 \pm 4.014$ \\
$\mathrm{Ca}(\mathrm{OH})_{2} 62.5 \mu \mathrm{g} / \mathrm{ml}$ & $77.59 \pm 6.525$ \\
$\mathrm{Ca}(\mathrm{OH})_{2} 125 \mu \mathrm{g} / \mathrm{ml}$ & $56.206 \pm 6.595$ \\
$\mathrm{Ca}(\mathrm{OH})_{2} 250 \mu \mathrm{g} / \mathrm{ml}$ & $49.49 \pm 13.530$ \\
\hline
\end{tabular}

Fibroblast cell death mechanism induced by calcium hydroxide in this study has not been clarified. It was probably caused by the alkaline $\mathrm{pH}$ of calcium hydroxide, which is almost $12.5-12.8^{15}$. Based on the previous in vitro study, pure calcium hydroxide has high initiation $\mathrm{pH}^{14}$ and that the hydroxyl ions are easily released in pure calcium hydroxide than in other preparations ${ }^{16}$. The $\mathrm{pH}$ can influence some of the cellular process such as cell metabolism, the changes of the cell's shape and mobility, the adjustment of transportation process and cell growth, cell proliferation and growth, conductivity and transport through the cell membrane, and isoosmotic cellular volume ${ }^{17}$.

The cell death mechanism caused by high alkaline condition is not clearly known, but the previous study demonstrated that mitochondria took an important part in this cell death mechanism. The mitochondrial damage was the initiation of cell death mechanism caused by alkaline condition. This condition induced the increase of mitochondrial trans-membran potential leading to the disfunction of mitochondria. Under normal condition, mitochondria is responsible for cell respiration and therefore maintains the proton gradient. The application of calcium hydroxide may cause an alkaline condition, and it may attract the proton away from mitochondria. The mitochondria adapts by increasing respiration which leads to the increase of radical superoxide. Under these circumstances, the level of mitochondrial trans-membrane potential elevation causes the increase of superoxide diffusion from cytosol to the mitochondrial membrane ${ }^{18}$. Another study suggests that the increasing radical superoxide may cause the de-energization of mitochondria and loss of energy stores, peroxidation, and disruption of lipid membranes, direct DNA damage, and activation of transcriptional factor sactivation of protein-1 (AP-1) and nuclear factor kappa beta (NF-KB) both of which promote transcription of cytokines and have been associated with induction of apoptotic cell death ${ }^{19}$.

There may be complicated molecular pathways involved in calcium hydroxide-induced cell death. It was reported that calcium hydroxide is able to induce the increase of intracellular calcium ion in $\mathrm{Ca}(\mathrm{OH})_{2}$-pretreated human pulp cells ${ }^{20}$. In fact the increase in intracellular calcium level can generate board spectrum of cellular processes ${ }^{21}$.

\section{Conclusion}

From our study it isconcluded that in vitro application of calcium hydroxide at certain concentration may cause fibroblast cell death, which may in part involve in pulp tissue destruction.

\section{Acknowledgements}

We would like to thank Mrs. Istini for the help during the experiment and also the staff of the Integrated Research and Testing Laboratory (LPPT) Unit II, Universitas Gadjah Mada, where this experiment was conducted.

\section{References}

1. Okiji T. 2002. Pulp as a connective tissue.In: Hargreavers, Goodi HE, Ed. Seltzer and Bender's Dental Pulp. Chicago: Quintessence Publishing Co.Inc.: 95-122.

2. Ferreira ANS, Silveira L, Genovese WJ, de Araújo VC, Frigo L, de Masquita RA, Guedes E. 2006. Effect of Gas laser on reactional dentinogenesis induction in human teeth. Photomed Laser Surg 24(3):358-65.

3. Harty FJ, Ogston R. 1993. Kamus Kedokteran Gigi. Penerbit Buku Kedokteran EGC.

4. Stanley H. 2002. Calcium hydroxide and vital pulp therapy. In: Hargreavers, Goodi HE, Ed. Seltzer and Bender's Dental Pulp. Chicago: Quintessence Publishing Co.Inc.: 309-24. 
5. Desai S, Chandler N. 2009. Calcium hydroxide based root canal sealers: A Review. J Endodont 35:475-8.

6. Kopel HM. 1997. The pulp capping procedure in primary teeth "revisited". ASDC J Dent Child 64: 327-33.

7. Markovic D, Zivojinovic V, Vucetic M. 2005. Evaluation of three pulpotomy medicaments in primary teeth. Eur J Paediatr Dent 6: 133-8.

8. Huth K C, Paschos E, Hajek-Al-Khatar N, Hollweck R, Crispin A, Hickel R, Folwaczny M. 2005. Effectiveness of 4 pulpotomy techniques - Randomized controlled trial. J Dent Res 84: 1144-8.

9. Zurn D, Seale NS. 2008. Light-cured calcium hydroxide vs formocresol in human primary molar pulpotomies: A randomized controlled trial. Pediatr Dent 30: 34-41.

10. Torabinejad M, Chivian N. 1999. Clinical applications of mineral trioxide aggregate. J Endodont 25: 197-205.

11. Bramante CM, Luna-Cruz LM, Sipert CR, Bernadineli N, Garcia RB, de Moraes IG, de Vasconcelos BC. 2008. Alveolar mucosa necrosis induced by utilization of calcium hydroxide as root canal dressing. Int Dent J 58: 81-5.

12. Piva E, Tarquỉnio SBC, Edmarco FF, Silva AF, de Araứjo VC. 2006. Immunohistochemical expression of fibronectin and tenascin after direct pulp capping with calcium hydroxide. Oral Surg Oral Med Oral Pathol Oral Radiol Endod 102: e66-e71.

13. Schmalz G, Schweikl H, Hiller KA. 2000. Release of prostaglandin $\mathrm{E}_{2}$, IL-6 and IL-8 from human oral epithelial culture models after exposure to compounds of dental materials. Eur J Oral Sci 108: $442-8$.

14. Pawińska M, Skrzydlewska E. 2003. Release of hydroxyl ions from calcium hydroxide preparations used in endodontic treatment.Rocz Akad Med Bialymst 48: 145-9.

15. Atthanassiadis B, Abbott PV,Walsh LJ. 2000. The use of calcium hydroxide, antibiotics and biocides as antimicrobial medicaments in endodontics. Aust Dent J 52: S64-S78.

16. Tamburic SD, Vuleta GM, Ognjanovic JM. 1998. "In vitro release of calciumand hydroxyl ions from two types of calcium hydroxide preparations," Int Endodon J 26:125-30.

17. Estrela C, Pẻcora JD, Silva RS. 1988. pH analyze of vehicles and calcium hydroxide paste. Braz Endodon J 3: 41-7.

18. Majima HJ, Oberley TD, Furukawa K, Mattso MP, Yen H, Szweda LI, St.Clair DK. 1998. Prevention of mitochondrial injury by manganese superoxide dismutase reveals a primary mechanism for alkaline-induced cell death. J Biol Chem 123: 8217-24.

19. Cobb JP, Hotchkiss RS, Karl IE, Buchman TG. 1996. Mechanisms of cell injury and death. $\mathrm{Br} J$ Anaesth 77: 3-10.

20. Wu H, Wen L, Shi J. 2001. Effect of calcium hydroxide on human pulp cell intracellular calcium ion in vitro. Zhonghua Kou Qiang Yi Xue Za Zhi 36: $128-9$.

21. Berridge MJ. 1993. Inositol trisphosphate and calcium signaling. Nature 361: 315-25. 